Egyptian Journal of Aquatic Biology \& Fisheries

Zoology Department, Faculty of Science,

Ain Shams University, Cairo, Egypt.

ISSN $1110-6131$

Vol. 25(1): 965 - 982 (2021)

www.ejabf.journals.ekb.eg

\title{
Pterophyllum scalare genome responses to silver nanoparticles
}

\author{
Raneem S. A. Al-amri ${ }^{1}$, Yasser M. Saad ${ }^{1,2^{*}}$, Majed A. M. Al- Shaeri ${ }^{1}$, Ahmed Atef ${ }^{1}$ \\ 1-Department of Biological Sciences, Faculty of Sciences, King Abdulaziz \\ University, Kingdom of Saudi Arabia. \\ 2-Genetics Lab., National Institute of Oceanography and Fisheries, Cairo, Egypt. \\ *Corresponding author: yasser_saad19@yahoo.com
}

\section{ARTICLE INFO \\ Article History: \\ Received: Jan. 30, 2021 \\ Accepted: Feb. 22, 2021 \\ Online: Feb. 28, 2021}

\section{Keywords:}

Fish

Silver

Nanoparticles

Markers

Protein variations

\begin{abstract}
The rapid emergence of nanoparticles technology holds an abundant capacity for its future applications in the aquatic environment. In this study, $P$. scalare was selected to be a model to evaluate the probable effects of silver nanoparticles on the fish genome responses. The homogeneity among the estimated fish samples was evaluated via the analysis of Inter simple sequence repeat (ISSR) markers. Fishes were reared for certain times under silver nanoparticle stresses. Four Isozyme systems (Esterase, Malate dehydrogenase, Superoxide dismutase and Alcohol dehydrogenase) and Protein separations (using the sodium dodecyl sulfate-polyacrylamide gel electrophoresis) were assayed to identify biochemical genetic markers in three different fish tissues (eye, gill and muscle) for all evaluated fish samples. No variations were appreciable among control and treated fish samples concerning protein separations. The separation of eye Esterase and Superoxide dismutase display clear differences between the control and the treated fishes. The results proposed that exposure to silver Nanoparticles can change the number and intensity of some isozymes in certain fish body organs. Isozyme separations have proven to be actual probes of differential gene expression in various fish samples. More biochemical markers could be developed to monitor aquatic environmental health especially in the term of water pollution ranks in the future Eco-Toxicological investigations.
\end{abstract}

\section{INTRODUCTION}

The rapid emergence of nanoparticle technology holds an abundant capacity for future applications due to their huge volume-specific surface areas with various surface activities than bulk (Farkas et al., 2017; Ibrahim et al., 2021).

In the recent decade, a lot of products were produced with nanoparticles as an active ingredient or as a part of the composition cosmetics of many fields. So, the nanoparticles had been introduced with the promise of different health benefits (Xia et al., 2009 ). The waste of these products is usually transferred to the sewer system and eventually to various water bodies where it was exposed to different aquatic organisms. The studies on the toxicity of nanoparticles for land animals of various systematic groups assessed sublethal and lethal concentrations, embryotoxicity, gene 
expression, cell proliferative activity, chromosome aberrations and fertility ( Warheit et al., 2007; Baun et al., 2008; Klaine et al., 2008).

A lot of studies confirmed that the silver nanoparticles caused gill pathology and mortality in the zebrafish, where the mean lethal dose (LD50) over $48 \mathrm{~h}$ was 0.9 and $7.2 \mathrm{mg} / \mathrm{l}$ nanoparticles, respectively (Griffit et al., 2007; 2008). Also, high concentrations of silver nanoparticles had been correlated with an increased rate of morphological abnormalities and mortality rate in the zebrafish larvae (Lee et al., 2007). The green synthesis of nanoparticles was introduced as a safe alternative to chemically synthesized particles. In the green synthesis, the organic solvents and chemical reagents are not used in the preparation of nanoparticles (NPs ). NPs have unique properties with their nanostructures (Raveendran et al., 2003). The atoms ordered to the nano-scale differ from the bulk metallic materials (Murphy et al., 2005).

The investigations in the field of toxicity effects of green synthesized nanoparticles on aquatic organisms are not yet saturated comparatively with the known pollutant substances such as pesticides (Ozgur and Rifat 2018; Laura et al., 2020). The gill tissues were considered a suitable target for exploring the effect of nanoparticles on fishes. Also, antioxidant fish enzymes could be used as biomarkers for exploring the toxicity of nanoparticle materials (Ozgur and Rifat 2018).

Different laboratory techniques are widely used for detecting the heavy metal accumulation in different fish tissues. These techniques are including gas chromatography (Fianko et al., 2011), high-performance liquid chromatography (Rao et al., 2010) and atomic absorption. Also, determination of protein separations and/or isozyme activities was recommended for exploring the effects of different environmental stresses including pollution on different organisms (Abd EL-Reheem $e t$ al., 2007; Skuratovskaya et al., 2017).

The probable effects of such materials on different aquatic organisms should be detected, tested and evaluated (Sabullah et al., 2015). From this point of view, the present study was designed to develop some biomarkers for exploring the fish genome responses to silver nanoparticles under certain conditions.

\section{MATERIALS AND METHODS}

\section{Fish sample source}

The Pterophyllum scalare (a freshwater fish belonging to the family Cichlidae) samples were obtained from the conservation of biological aquatic resources research group (CBARRG), Biological Sciences Department, Faculty of Sciences, King Abdulaziz University.

Estimation of the homogeneity within the evaluated fishes: DNA extraction and amplification

The DNA was extracted from caudal fin tissues as described by Saad et al., (2013). 


\section{ISSR analysis \\ Inter Simple Sequence Repeats (ISSR)}

A total of 10 ISSR primers were tested to evaluate the homogeneity within the estimated fish samples at a molecular level. The ISSR primer sequences and codes were presented in Table (1).

PCR reactions were prepared as described by Saad et al., (2013) with some modifications. The PCR program consisted of one cycle for $3 \mathrm{~min}$. at $96^{\circ} \mathrm{C}, 40$ cycles for $\left(30 \mathrm{sec}\right.$. at $96^{\circ} \mathrm{C}, 30 \mathrm{sec}$. at $42{ }^{\circ} \mathrm{C} \mathrm{\&} 1 \mathrm{~min}$. at $\left.72^{\circ} \mathrm{C}\right)$ and one cycle for $10 \mathrm{~min}$. at $72^{\circ} \mathrm{C}$. The separated PCR products $(1.6 \%$ agarose gels $)$ were photographed. Data were analyzed and presented.

\section{Green synthesis of AgNPs}

The synthesis of AgNPs with C.gileadensis bark extracts (obtained from CBARRG) was carried out by mixing the aqueous solution of silver nitrate $(0.216 \mathrm{~g} / \mathrm{L})$ with the aqueous bark extracts in the ratio of $5: 1(\mathrm{v} / \mathrm{v})$. The previous mixture was stirred and then left at room temperature for 24 hours on the shaker. After 24 hours, the product contents were centrifuged at $10,000 \mathrm{rpm}$ at $4^{\circ} \mathrm{C}$ for 12 minutes for removing the presence of probable biological admixtures.

\section{Quantify the conversion of $\mathrm{Ag}^{+}$to $\mathrm{AgNP}$}

The conversion of $\mathrm{Ag}^{+}$to $\mathrm{AgNP}$ was quantified by the inductively coupled plasma atomic emission spectroscopy (ICP-AES) as described by Rahman et al., (2018).

\section{Experimental design}

\section{Determination of LC50}

Fish $(n=75)$ with an average weight of $4.89 \pm 0.2 \mathrm{~g}$ and lengths of $5.804 \mathrm{~cm}$ $\pm 0.1 \mathrm{~cm}$ were acclimated for 10 days in well-aerated conditions. The averages of water temperature and $\mathrm{pH}$ value were $21.05 \pm 0.03$ and $8.1 \pm 0.07$ respectively. All fishes were fed a commercial diet (25\% protein).

The fish samples were divided into 5 groups (5 fish of each group, in 3 replicates) each as follows: Group 1 (water, control group), Group 2 (water with plant extract),

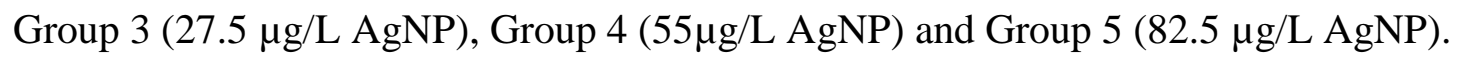

The LC50 values at certain AgNP concentrations were calculated using the AAT Bioquest, Inc. (2021, January 20). Quest Graph ${ }^{\mathrm{TM}}$ LC50 Calculator (https://www.aatbio.com/tools/lc50-calculator) at the durations (24, 48 and 72h) of exposure.

\section{Evaluating the effects of the AgNPs on the fish genome responses}

Fish individuals were acclimated for 10 days in well-aerated conditions (The light: dark regime was set to $16: 8 \mathrm{~h}$ ). The averages of water (dechlorinated tap water) temperature and $\mathrm{pH}$ value were $21.05 \pm 0.03$ and $8.1 \pm 0.07$ respectively.

An experiment was carried out for evaluating the effects of AgNPs on the fish genome responses during three different times $(\mathrm{ta}=12 \mathrm{~h}, \mathrm{tb}=24 \mathrm{~h}$ and $\mathrm{tc}=48 \mathrm{~h})$ compared with the control ( $\mathrm{c} 1$ and $\mathrm{c} 2$ ). The fish were feed with the commercial diet for five days in good aerated condition (Elsebaie et al., 2014). The feeding possess was equivalent to $5 \%$ of fish body weight. Accumulated fecal and feed waste was removed 
from ponds every $12 \mathrm{~h}$. Also, one day before administering experimental treatments, the fish feeding was stopped.

A total of 15 Polypropylene tanks (15L size) were separated into five groups (distilled water, Water with plant extract, AgNPs $(27.5 \mu \mathrm{g} / \mathrm{L})$ solution for ta, tb and tc. Using triplicate tests, the fish were exposed to AgNPs based on a semi-static exposure regime. All the tanks were well aerated at $20 \pm 1{ }^{\circ} \mathrm{C}$. The fish individuals were randomly separated into the tanks $(n=3)$. So, each group had 9 fish individuals.

All fish were removed from each pond according to the scheduled times. Each sample was rinsed with deionized water to remove any AgNPs on the fish surface. The fish samples were killed by severing the spinal cord (Farkas et al., 2017). The tissue samples (eyes, gills and muscles) were frozen at $-80^{\circ} \mathrm{C}$ until the analysis.

\section{Protein extraction, purification and sample preparation}

The Saline soluble proteins were extracted from each fish tissue type (eyes, gills and muscles) as explained by Rashed et al., (2007) with minor modifications. A total of $0.05 \mathrm{~g}$ from each tissue sample was powdered in liquid nitrogen then extracted in $400 \mu \mathrm{l}$ of $0.85 \% \mathrm{NaCl}$ solution $(\mathrm{pH}=8)$. The products were centrifuged at 12000 $\mathrm{rpm} / 15 \mathrm{~min}\left(4^{\circ} \mathrm{C}\right)$. The supernatants were transferred into new Eppendorf tubes. 100 $\mu \mathrm{l}$ of lauding dye $\left(50 \%\right.$ glycerol, $0.5 \mathrm{~g}$ bromophenol blue and $\mathrm{ddH}_{2} \mathrm{O}$ up to $100 \mathrm{ml}, \mathrm{pH}$ $=8$ ) was added for each purified sample.

\section{SDS-PAGE}

Each purified protein sample $(50 \mu \mathrm{l})$ was prepared for separation using Sodium Dodecyl Sulfate-Polyacrylamide Gel Electrophoresis or SDS-PAGE (Abdel-Reheem et al., 2007). Samples were applied to $14 \%$ polyacrylamide gel electrophoresis. The gels were prepared as mentioned by Abdel-Reheem et al., (2007). Electrophoresis conditions, Staining and De-staining were carried out as described by Mansour et al., (2012).

\section{Isozyme electrophoresis}

Malate dehydrogenase (Mdh), Alcohol dehydrogenase (Adh), Esterase (Est) with substrates ( $\alpha$-naphthyl acetate) and Superoxide dismutase (Sod) isozyme systems were applied to detect the probable biochemical genetic variations among treated and control tissue samples (eyes, gills and muscles). Electrophoretic conditions, gel preparation, were carried out according to Mansour et al., (2012). The staining of the gels was carried out as described by Pasteur et al., (1988) with minor modifications as reported in Saad et al., (2009).

\section{Statistical analysis:}

All experiments were performed in triplicate. Identification of lethal concentration values was calculated as described by Gulec et al., (2013) with some modification as described by Elsebaie et al., (2014).

Protein and isozyme Gel patterns were analyzed as described by Mansour et al., (2012). ISSR patterns were analyzed as described by Saad et al., (2013). 


\section{RESULTS}

\section{Evaluation of homogeneity among $\boldsymbol{P}$. scalare samples based on ISSR variations}

A total of 10 ISSR (Inter simple sequence repeats) primers (Table 1) were selected to generate ISSR fragments (Figure 1). After the validation of selected ISSR primers via polymerase chain Reaction methodology, the data were analyzed to calculate the homogeneity value among the evaluated fish samples.

The numbers of DNA fragments were calculated among generated banding patterns. It ranged from 2 bands (Primers 6) to 11 bands (primers 1 and 2). Generally, the results of the analyzed ISSR banding patterns showed that the percentage of polymorphic loci was low. The ISSR band frequencies were calculated for each selected ISSR primer. The averages of these band frequencies were presented in Figure (2). The data analysis showed that the homogeneity values among the evaluated fish samples were extremely high (0.98).

\section{Calculation of lethal concentration ( $\mathrm{LC50})$ values}

After the acclimatization period (10 days), each fish group ( $n=15)$ was exposed to a certain AgNPs. The water temperature and $\mathrm{pH}$ value were measured each 12h. During the experiment period, the feeding was stopped. The general behavior of each fish group was observed and registered. The Dead specimens were eliminated immediately after death. Also, the percentages of mortality values were calculated.

Different mortalities were observed at the three fish groups (Group 3, Group 4 and Group 5). No mortality was observed in both fish groups 1 (fish in only water, control group) and 2 (fish in water with plant extract).

The LC50 value of AgNPs for the evaluated fishes was $59.4 \mu \mathrm{g} / \mathrm{L}$.

\section{Analysis of protein electrophoresis banding patterns}

The separation of protein bands was varied among the evaluated fish body organs (eyes, gills and muscles). The total numbers of detected protein bands were 23, 26 and 24 in eyes, gills and muscles respectively (Figures 3-A, B and C).

Also, the protein band densities and intensities differed among the evaluated fish body organs. On the contrary, gills had the lowest intensities (Figures 3-B). The distributions of protein bands were similar within each evaluated organ soluble protein extract separations in all applied protein samples. With regards to different organs, no treatment effects were recorded in all estimated soluble protein separations.

\section{Analysis of isozyme banding pattern variations}

The results revealed some different fish tissues responses among different time intervals under certain AgNP concentration.

All fish samples yield a pattern of anodally moving isozyme bands. The electrophoretic patterns and the numbers of detected isozyme bands were presented in Tables (2) and (3) respectively. 
Table 1: The ISSR primer code, name, sequences and number of detected bands.

\begin{tabular}{cllcccc}
\hline Primer & Name & Sequence & TNB & PB & CB & SD \\
\hline P1 & AW3 & (GT)6-RG & 11 & 0 & 11 & 0 \\
P2 & IT1 & (CA)8-GT & 11 & 0 & 11 & 0 \\
P3 & IT3 & (GAG)4-AG & 10 & 3 & 7 & 0.09 \\
P4 & HB11 & (GT)6-CC 3' & 7 & 0 & 7 & 0 \\
P5 & SAS1 & (GTG)4-GC & 6 & 1 & 5 & 0.21 \\
P6 & CHRIS & (CA)7-YG & 2 & 0 & 2 & 0 \\
P7 & TERRY & (GTG)4-RC & 10 & 0 & 10 & 0 \\
P8 & SAS3 & (GAG)4-G & 8 & 0 & 8 & 0 \\
P9 & BECKY & (CA)7-YC & 6 & 0 & 6 & 0 \\
P10 & 814 & (CT)8-TG & 7 & 0 & 7 & 0 \\
\hline $\begin{array}{l}\text { TNB= Total number of bands, PB= Polymorphic bands, } \\
\text { CB= Common bands and SD= Slandered deviation. }\end{array}$
\end{tabular}

\section{Esterase isozyme variations}

The electrophoretic patterns of the Esterase (with $\alpha$-naphthyl acetate) isozyme (Figures 4, 5 and 6) in the three different fish organs (eyes, gills and muscles) revealed distinguished Esterase bands. The separated fish esterase isozymes showed very intense bands in all evaluated fish tissues. The numbers of detected Esterase bands were variable among evaluated fish organs under the experimental conditions. Eye esterase (Figure 4 ) bands ( 10 bands) were the most intense and informative bands relatively. There are three common Esterase bands were detected in the eye Esterase at certain relative fronts $(0.08,0.3$, and 0.34$)$. One Esterase band (at $\mathrm{RF}=0.06$ ) was present in all AgNP treatments while absent in both c1 and c2 samples. A total of five Esterase bands at certain $\operatorname{RF}(0.48,0.54,0.68,0.7$ and 0.8$)$ were specific for all tc samples (tc1, tc2 and tc3). The band at $\mathrm{RF}=(0.76)$ was absent in all tc samples.A total of 4 gill Esterase isozymes (Figure 5) were detected according to the band relative mobility's. Only one band $(\mathrm{RF}=0.886)$ was absent in the (ta) samples.

A total of 8 muscle esterase bands were identified. On the other hand, No polymorphic muscle Esterase bands were observed (Figure 6). 


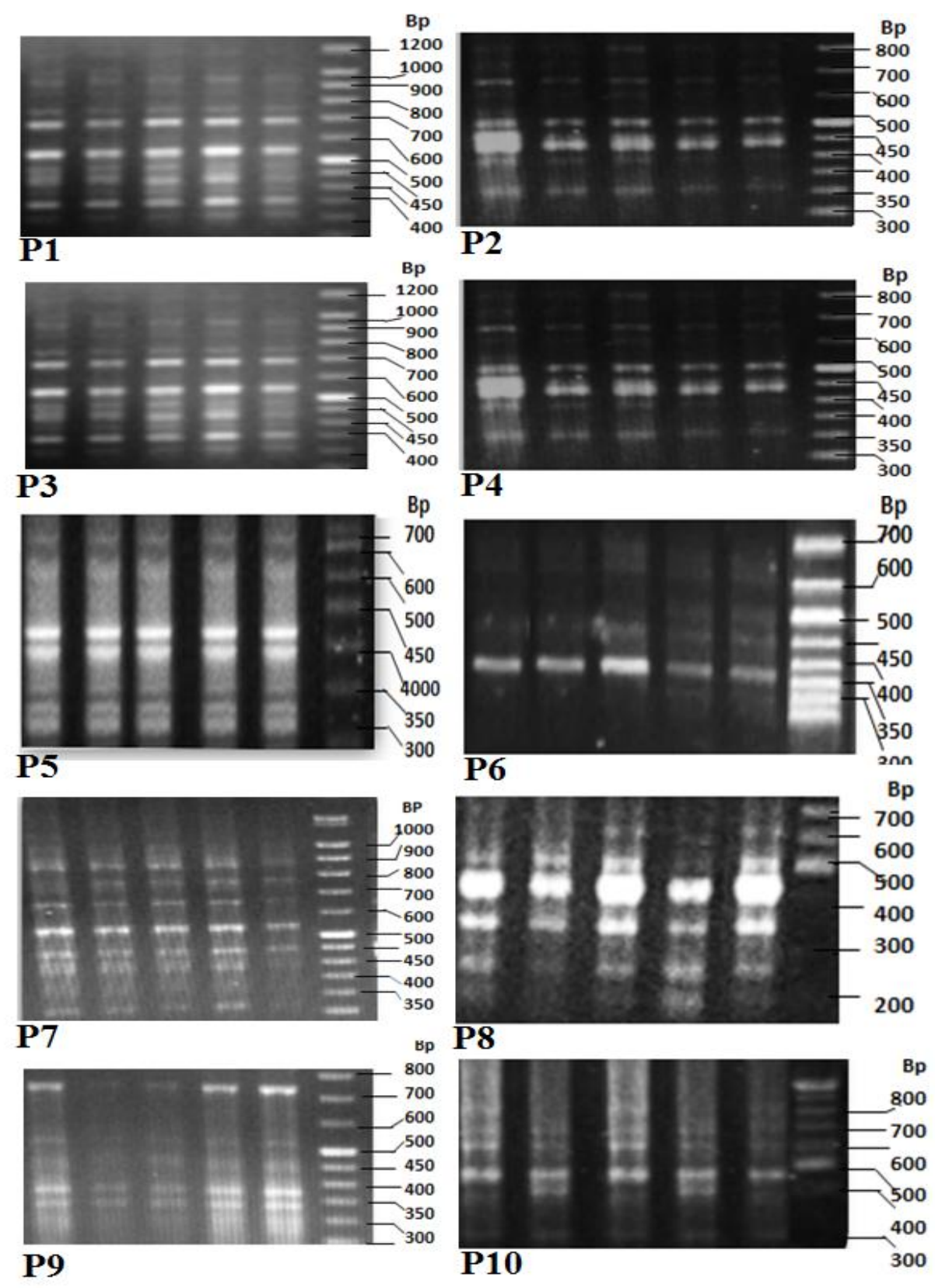

Fig.1: Separation of ISSR band variations among the evaluated fish samples .P= ISSR Primer, $\mathrm{B} p=$ base pair. 


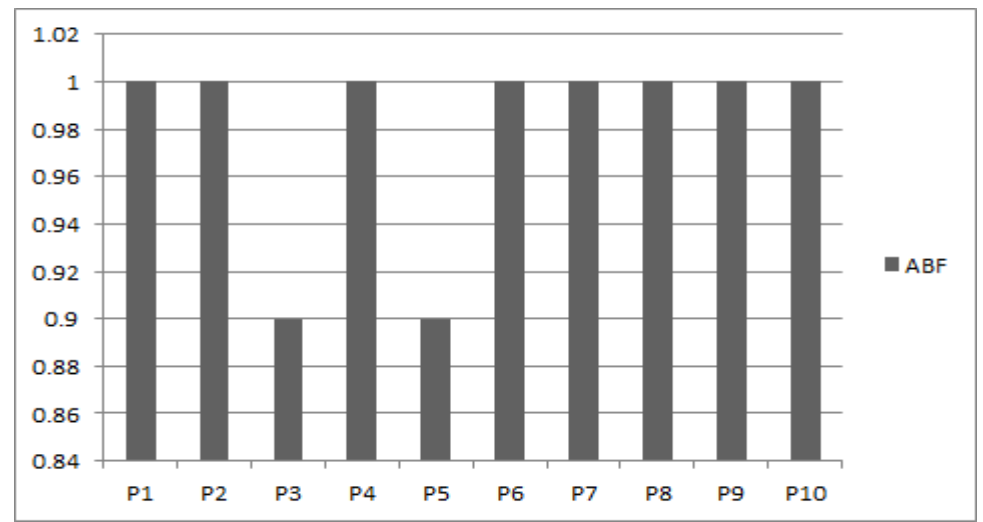

Fig.2: Average of ISSR band frequencies for each selected ISSR primer. P= ISSR primer.
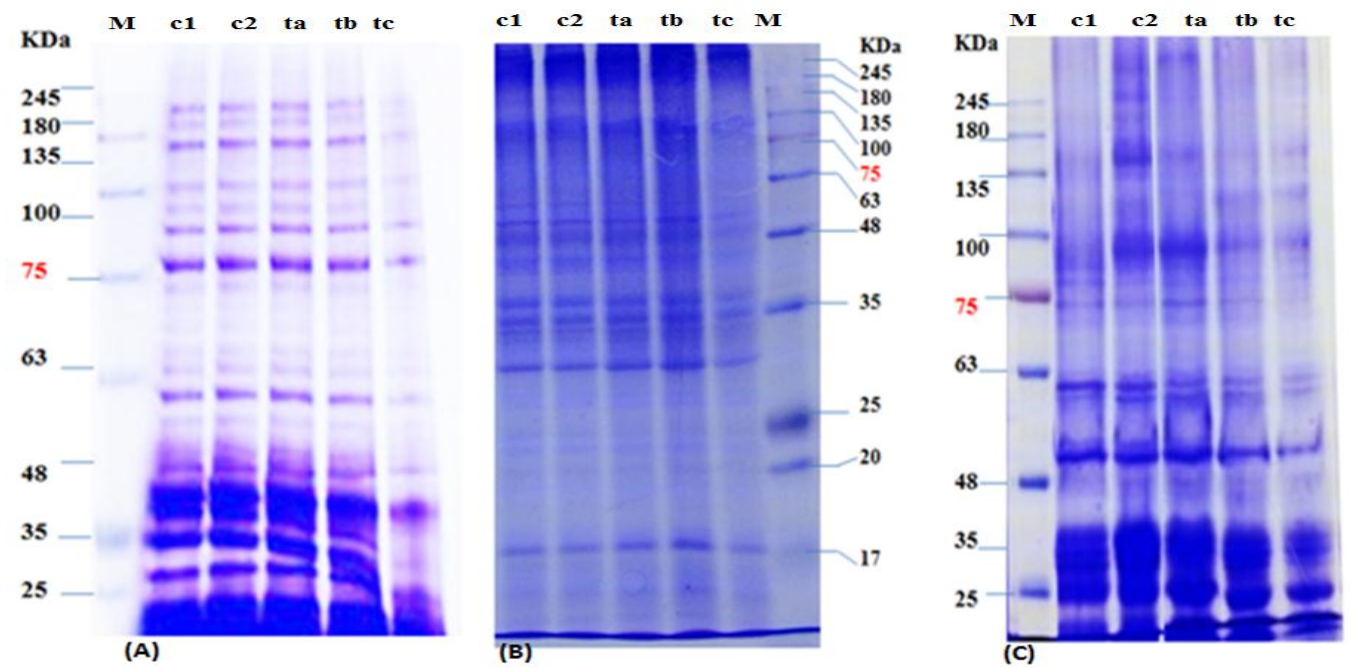

Fig.3: Separation of protein (SDS-PAGE) bands from different fish tissue extracts. A=Eye soluble protein bands, $\mathrm{B}=$ Gills soluble protein bands and $\mathrm{C}=$ Muscle soluble protein bands. $\mathrm{ta}=12 \mathrm{~h}, \mathrm{tb}=24 \mathrm{~h}, \mathrm{tc}=48 \mathrm{~h}, \mathrm{c} 1=$ control 1 and $\mathrm{c} 2=$ control 2.

Table 2:The resolution of four enzymes and protein electrophoresis resolutions the three types of P.scalare tissues (Under the experimental conditions).

\begin{tabular}{|c|c|c|c|c|c|c|c|}
\hline \multicolumn{2}{|l|}{ Tissue } & \multicolumn{2}{|c|}{ Eye } & \multicolumn{2}{|c|}{ Gills } & \multicolumn{2}{|c|}{ Muscles } \\
\hline System & En & resolution & NDB & resolution & NDB & resolution & NDB \\
\hline SDS-PAGE & & +++ & 25 & ++ & 34 & +++ & 26 \\
\hline Est & 3.1.1.1 & +++ & 10 & +++ & 4 & +++ & 8 \\
\hline Sod & $\begin{array}{l}1.15 .1 . \\
1\end{array}$ & +++ & 11 & +++ & 6 & + & 1 \\
\hline Mdh & $\begin{array}{l}\text { 1.1.1.3 } \\
7\end{array}$ & +++ & 3 & - & - & +++ & 4 \\
\hline Adh & 1.1.1.1 & + & 3 & +++ & 5 & + & 4 \\
\hline
\end{tabular}

SDS $=$ Sodium Dodecyl Sulfate-Polyacrylamide Gel Electrophoresis, Est.= Esterase, Sod $=$ Superoxide dismutase, $\mathrm{Mdh}=$ Malate dehydrogenase, $\mathrm{Adh}=$ Alcohol dehydrogenase, En= Enzyme number, +++= strong, ++=Moderate, $+=$ Weak, $-=$ No detectable reaction and $\mathrm{NBD}=$ Number of detected bands. 
Table 3: Numbers of detected bands in each treatment for each fish tissue.

\begin{tabular}{ccccccccccccc}
\hline & \multicolumn{4}{c}{ Eye } & \multicolumn{4}{c}{ Gills } & \multicolumn{5}{c}{ Muscles } \\
\hline & Est & Sod & Mdh & Adh & Est & Sod & Mdh & Adh & Est & Sod & Mdh & Adh \\
\hline $\boldsymbol{c} \boldsymbol{1}$ & 5 & 10 & 2 & 3 & 4 & 2 & - & 4 & 8 & 1 & 4 & 4 \\
$\boldsymbol{c} \boldsymbol{2}$ & 5 & 10 & 2 & 3 & 4 & 2 & - & 4 & 8 & 1 & 4 & 4 \\
$\boldsymbol{t a}$ & 5 & 10 & 2 & 3 & 3 & 3 & - & 5 & 8 & 1 & 4 & 4 \\
$\boldsymbol{t} \boldsymbol{b}$ & 5 & 9 & 2 & 3 & 4 & 4 & - & 5 & 8 & 1 & 4 & 4 \\
$\boldsymbol{t c}$ & 9 & 7 & 3 & 3 & 4 & 4 & - & 4 & 8 & 1 & 4 & 4 \\
\hline $\boldsymbol{A B F}$ & 0.6 & 0.8 & 0.8 & 1 & 0.9 & 0.56 & - & 0.92 & 1 & 1 & 1 & 1 \\
\hline $\boldsymbol{S D}$ & 0.4 & 0.3 & 0.4 & 0 & 0.1 & 0.36 & - & 0.1 & 0 & 0 & 0 & 0 \\
\hline
\end{tabular}

Est. $=$ Esterase, Sod $=$ Superoxide dismutase, $\mathrm{Mdh}=$ Malate dehydrogenase, $\mathrm{Adh}=\mathrm{Alcohol}$ dehydrogenase, $-=$ No detectable reaction, $\mathrm{c}=$ control, $\mathrm{ta}=$ first time, $\mathrm{tb}=$ second time, $\mathrm{tc}=$ third time, $\mathrm{ABF}=$ average of band frequencies and $\mathrm{SD}=\mathrm{Standers}$ deviation.

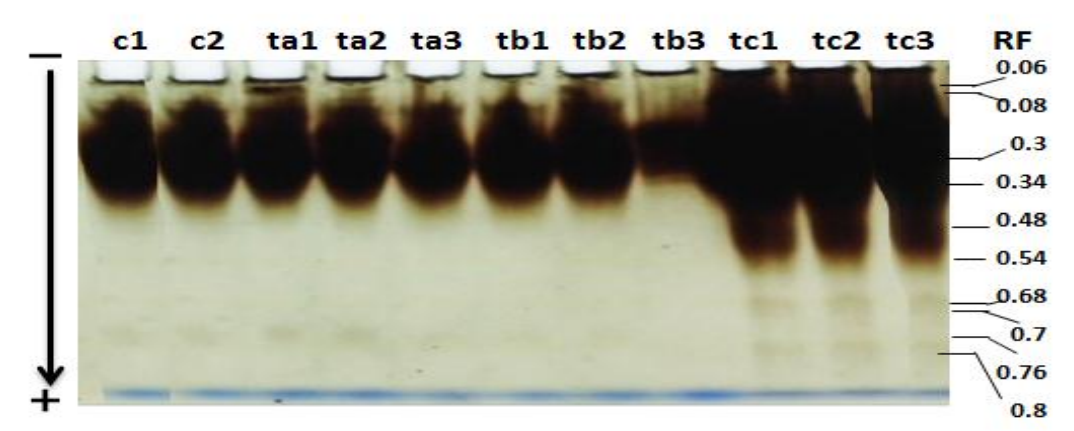

Fig.4: Separation of Esterase isozyme bands from fish Eye tissue extracts. $\mathrm{ta}=12 \mathrm{~h}, \mathrm{tb}=24 \mathrm{~h}, \mathrm{tc}=48 \mathrm{~h}, \mathrm{c} 1=$ control 1 and $\mathrm{c} 2=$ control 2 .

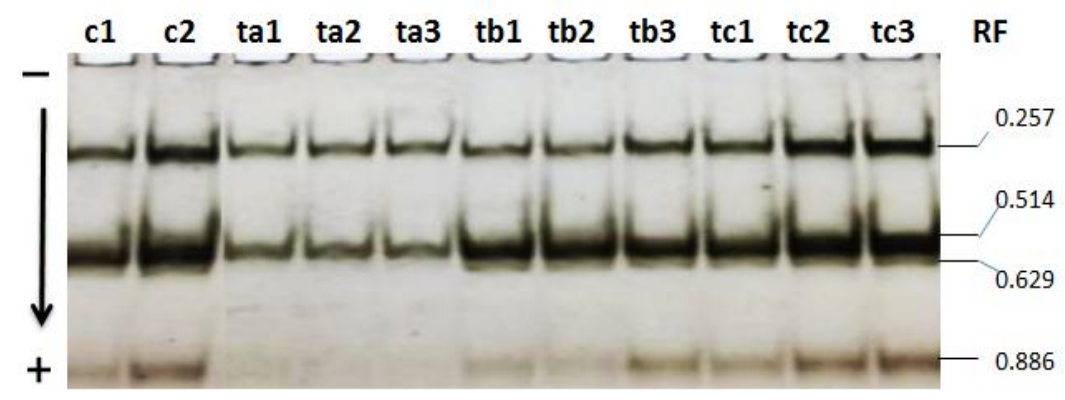

Fig.5: Separation of Esterase isozyme bands from fish gill tissue extracts. $\mathrm{ta}=12 \mathrm{~h}, \mathrm{tb}=24 \mathrm{~h}, \mathrm{tc}=48 \mathrm{~h}, \mathrm{c} 1=$ control 1 and $\mathrm{c} 2=$ control 2 . 


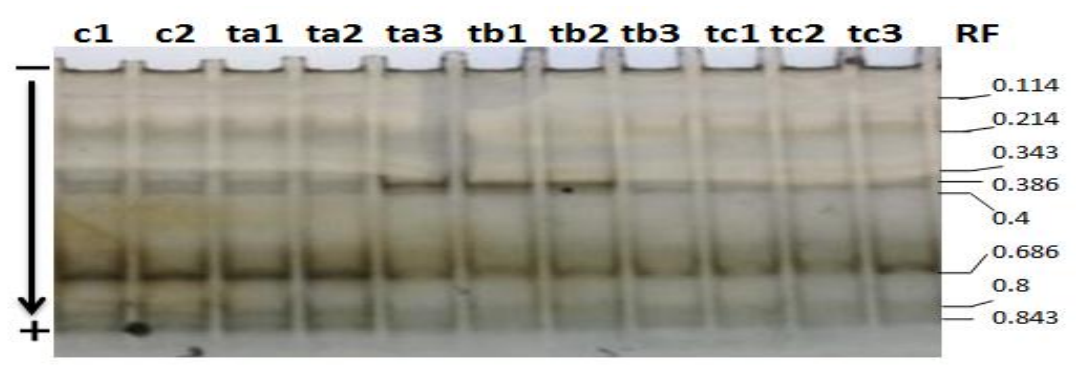

Fig.6: Separation of Esterase isozyme bands from fish muscle tissue extracts. $\mathrm{ta}=12 \mathrm{~h}, \mathrm{tb}=24 \mathrm{~h}, \mathrm{tc}=48 \mathrm{~h}, \mathrm{c} 1=$ control 1 and $\mathrm{c} 2=$ control 2 .

\section{Superoxide dismutase (Sod)}

The electrophoretic patterns of the Sod isozymes in eyes (Figure 7), gills (Figure 8) and muscles were revealed distinguished Sod bands. The numbers of identified Sod bands were diverse among the evaluated fish tissues under the experimental conditions. Eye Sod (Figure 7) bands (11 bands) were the most intense and informative bands relatively.

There are 6 common Sod bands were detected in eye Sod at certain relative fronts $(0.08,0.12,0.24,0.3,0.48$ and 0.62$)$.

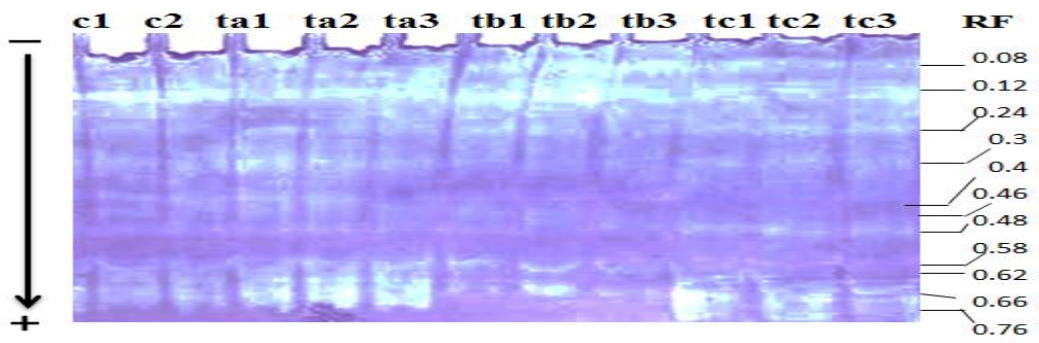

Fig.7: Separation of Superoxide dismutase isozyme bands from fish Eye tissue extracts. ta= $12 \mathrm{~h}, \mathrm{tb}=24 \mathrm{~h}, \mathrm{tc}=48 \mathrm{~h}, \mathrm{c} 1=$ control 1 and $\mathrm{c} 2=$ control 2 .

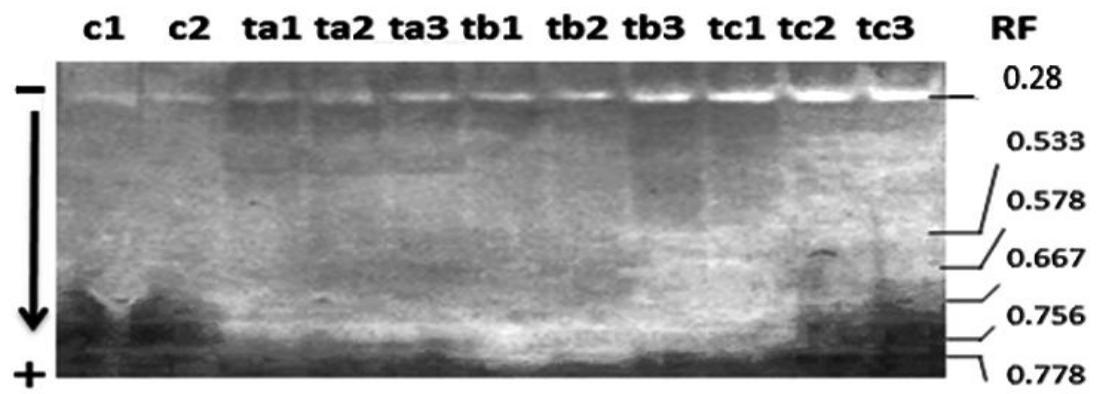

Fig.8: Separation of Superoxide dismutase isozyme bands from fish Gill tissue extracts. ta= $12 \mathrm{~h}, \mathrm{tb}=24 \mathrm{~h}, \mathrm{tc}=48 \mathrm{~h}, \mathrm{c} 1=$ control 1 and $\mathrm{c} 2=$ control 2 .

A total of three Sod bands (at $\mathrm{RF}=0.4,0.46$ and 0.58 ) were present in all $\mathrm{c} 1$, $\mathrm{c} 2$, ta and tb individuals. On the other hand, these bands were absent in all the tc samples. Also, one Sod band $(\mathrm{RF}=0.76)$ was identified as the specific band for all tc samples. Regarding the gills Sod, a total of 6 bands were detected at certain relative fronts $(0.28,0.533,0.578,0.667,0.756$ and 0.778$)$. Out of the 6 detected Sod bands, two bands were considered as common bands at relative fronts 0.28 and 0.533 ). There are two Sod bands $(\mathrm{RF}=0.578$ and 0.667$)$ that were specific to the tc samples. 
Concerning the muscles tissue extracts, only one faint uninformative Sod band was detected at $\mathrm{RF}=0.4$.

\section{Malate dehydrogenase (Mdh)}

The electrophoretic patterns of the Mdh isozyme (Figures 9 and 10) in two different fish organs (eye and muscle) revealed distinguished Mdh bands.

Concerning the eye Mdh (three bands), two common bands at the relative fronts $(\mathrm{RF}=0.4$ and 0.46) were detected (Figure 9). The third Mdh band was only detected in the tc (tc1, 2 and 3) tissue samples $(\mathrm{RF}=0.6)$. On the other hand, no clear polymorphic muscle Mdh bands were observed (Figure 10).

\section{Alcohol dehydrogenase (Adh)}

The same Adh bands at the same positions were detected in both treated and control samples in the eye ( 3 bands) and muscle ( 4 bands) fish tissues (Tables 2 and $3)$. However, the numbers of Alcohol dehydrogenase bands were changed by the NP$\mathrm{Ag}$ in the evaluated gill tissues (Figure 11). One Adh band was absent in the tc samples at RF (0.333). Also, the band at RF (0.13) was absent in the control samples while this band was present in the other samples.

The distribution of Band frequencies (BF) and Relative fronts (RF) of each evaluated isozyme in each estimated fish tissue are presented in Figure (12).

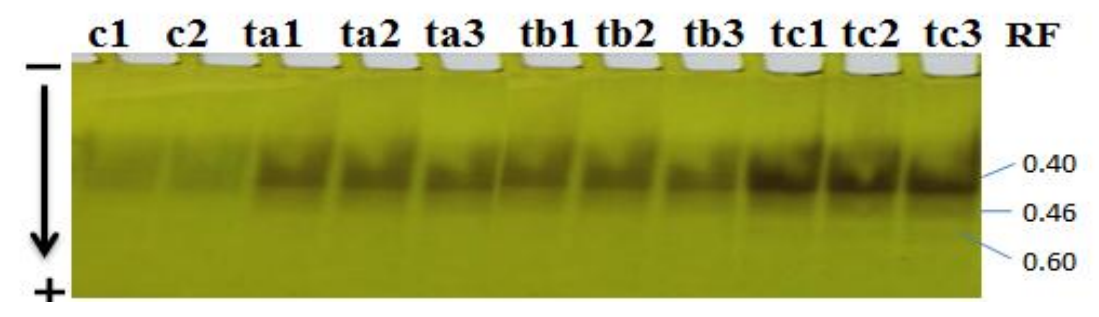

Fig.9: Separation of Malate dehydrogenase isozyme bands from fish Eye tissue extracts. ta= $12 \mathrm{~h}, \mathrm{tb}=24 \mathrm{~h}, \mathrm{tc}=48 \mathrm{~h}, \mathrm{c} 1=$ control 1 and $\mathrm{c} 2=$ control 2 .

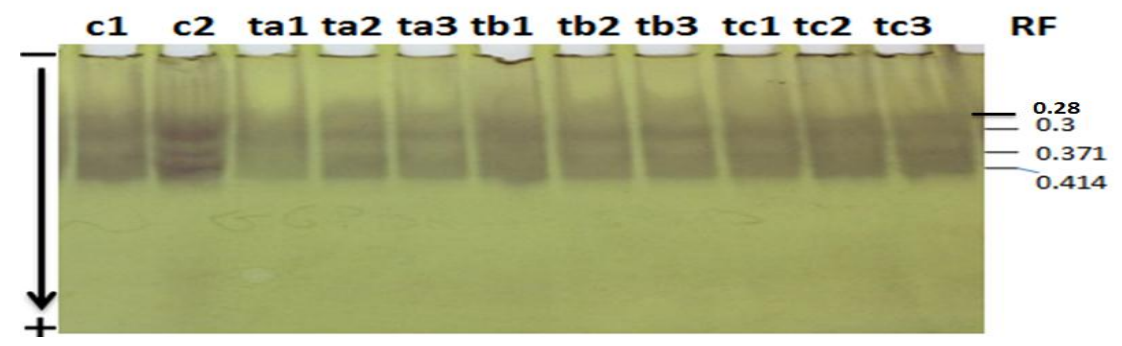

Fig. 10: Separation of Malate dehydrogenase isozyme bands from fish muscle tissue extracts. $\mathrm{ta}=12 \mathrm{~h}, \mathrm{tb}=24 \mathrm{~h}, \mathrm{tc}=48 \mathrm{~h}, \mathrm{c} 1=$ control 1 and $\mathrm{c} 2=$ control 2 .

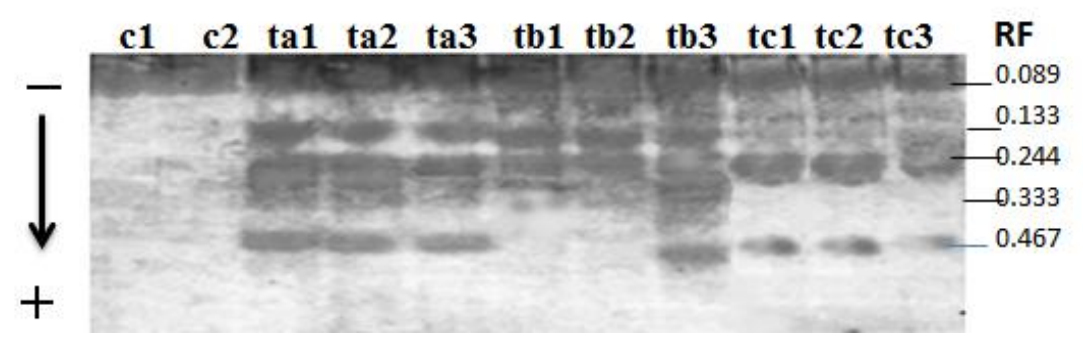

Fig.11: Separation of Alcohol dehydrogenase isozyme bands from fish gill tissue extracts ta= $12 \mathrm{~h}, \mathrm{tb}=24 \mathrm{~h}, \mathrm{tc}=48 \mathrm{~h}, \mathrm{c} 1=$ control 1 and $\mathrm{c} 2=$ control 2 . 

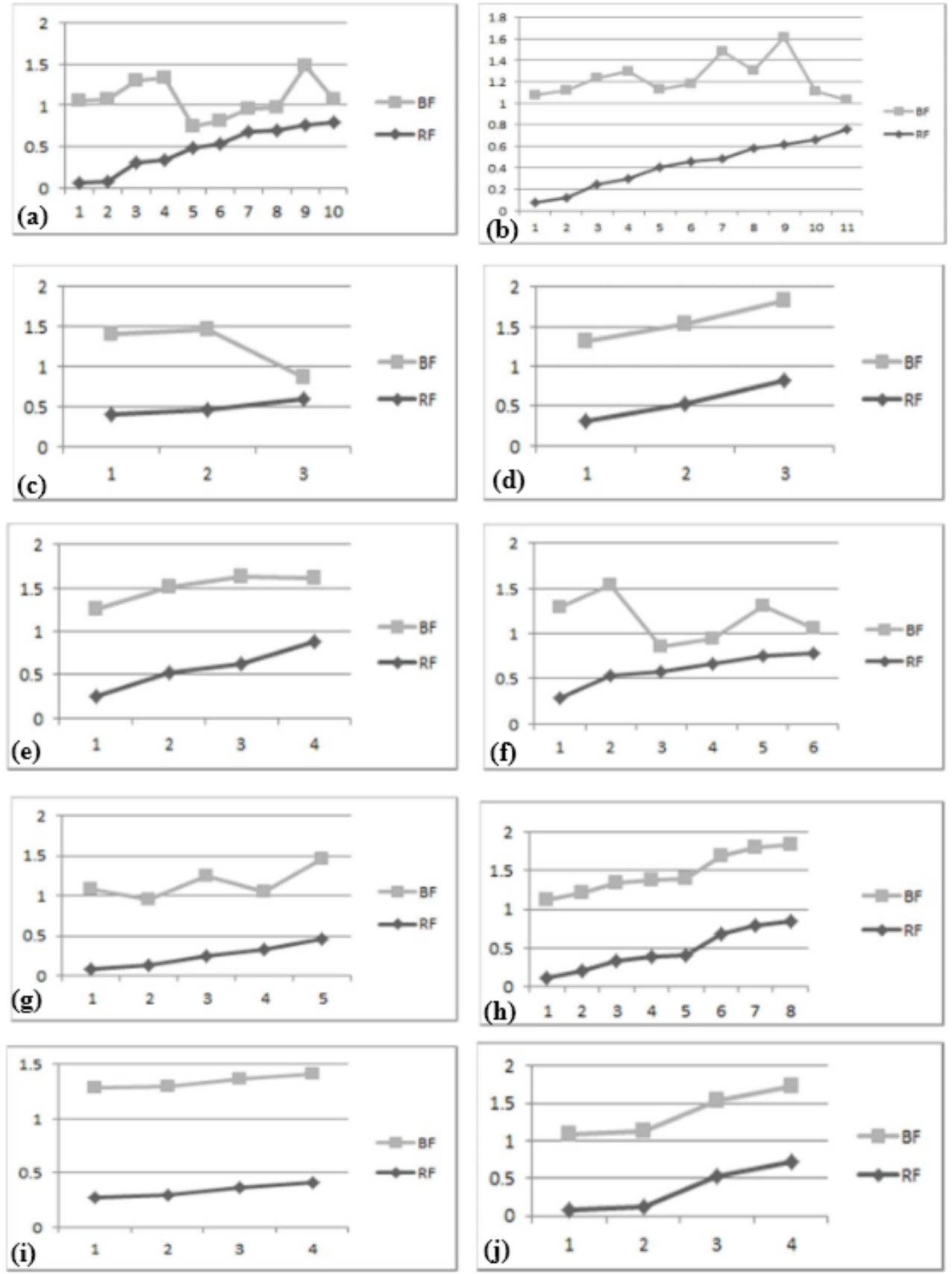

Fig.12: Distribution of Band frequencies (BF) and Relative fronts (RF) of each evaluated isozyme in each estimated fish tissue. $(a)=$ Eye Est., $(b)=$ Eye Sod, $(c)=$ Eye Mdh, $(d)=$ Eye Adh, (e)= Gill Est., $(\mathrm{f})=$ Gill Sod, $(\mathrm{g})=$ Gill Adh, $(\mathrm{h})=$ Muscle ESt., $(\mathrm{i})=$ Muscle Mdh and $(\mathrm{j})=$ Muscle Adh.

\section{DISCUSSION}

The recent applications, challenges and perspectives of AgNPs biosecurity in the aquaculture industry are explained and discussed by Laura et al., (2020).

In the present investigation, the AgNPs were synthesized using the green method. This method was applied due to its eco-friendly and low cost (Sharma et al., 2009; Laura et al., 2020). We evaluated the effects of silver nanoparticles on the P.scalare genome responses. Four Isozyme systems (Esterase, Malate dehydrogenase, 
Alcohol dehydrogenase and Superoxide dismutase) and Protein electrophoresis (SDSPAGE) were applied to identify genetic markers (as bioindicators) in the three different fish tissues (eyes, gills and muscles) for all evaluated fish groups.

Protein and isozyme electrophoresis is among the most cost-effective methods of studying the genetic phenomena at the molecular and/or biochemical levels (Robert et al., 1996; Saad et al., 2009; Mansour et al., 2012).

The homogeneity value among the estimated $P$. scalare samples was reflected by the high band frequencies generated by the selected ISSR primer. This sensitive method was applied due to its efficiency in discrimination between fish individuals within a certain fish population. Also, this method has value in studying speciation in various animal taxa (Saad and Elsebaie 2020) including fishes (Omar et al., 2020).

Allozyme genotypes have been extensively identified as bio-indicators for water quality due to its sensitivity to various environmental stressors. Allozyme variations might be correlated to environmental stressors such as metal concentrations, temperature, salinity and $\mathrm{pH}$ variability (Fore et al., 1995). So, the changes in identified allele frequency in evaluated fishes could be affected by experimental conditions as revealed from the separation of the band frequencies.

The proteins from three fish tissues (Eyes, Gills and white Muscles) were extracted for developing biomarkers under our experimental conditions. A total of two tissues (eyes and gills) were affected by the experimental conditions. No variations were detected in the case of muscle extract. This reflects the conservative features of fish muscle proteins.

The distributions of AgNPs in various fish (Scophthalmus maximus) tissues were evaluated by Farkas et al., (2017). They found that AgNP was detectable in most fish tissues despite the relatively short daily exposure duration ( $2 \mathrm{~h}$ ). The AgNPs were extremely attached to gill surfaces and/or stuck in the fish gill mucus. Another study observed that the dissolved Ag was accumulated in marine teleost fish (Platichthys flesus) liver (Hogstrand et al., 2002). So, the real effects of AgNPs on tissue functions should be evaluated in different fish tissues at various levels.

The highest allele frequency values of the four applied isozyme systems were calculated in the muscle tissues. On the other hand, the allele frequency values in the other two evaluated tissues (eye and gills) were lower than allele frequency in the muscles. Also, out of the four applied isozyme systems (Est., Sod, Mdh and Adh), Esterase and Superoxide dismutase were informative in discrimination among the fish samples under the experimental conditions. The Adh loci were invariant in the muscle and eye fish tissues. Concerning the gills tissues, the Adh was informative in discrimination between the treated and control groups.

We observed that, the effects of silver nanoparticles on the different fish tissues were variables. This observation was also registered by Johari et al., (2015). Chae et al. (2009) found that the fish exposed to AgNPs first increased expression of Glutathione S-transferase A (GST) in the liver of O.latipes. A similar observation was confirmed by Pham et al. (2012). On the other hand, over time GST expression values were decreased in the same species (Chae et al. 2009). 
The number of isozymes and the intensity of isozyme bands in the fish exposed to AgNPs were increased in the eyes and gills extracts through time. Also, a group of distinct isozymes bands was specific for certain treatments. For example, some Sod and Est bands in gills and eye extracts were only present in tb and tc samples. Also, a total of five Esterase bands at certain RF $(0.48,0.54,0.68,0.7$ and $0.8)$ were specific for all tc samples (tc1, tc2 and tc3). This could be due to those certain genes in certain tissues exhibit increasing in their expression levels under metal and/or Nano-metal materials exposure.

The antioxidants such as superoxide dismutase, ascorbic acid, Metallothionein and glutathione peroxidase were acting as the vanguard of cellular defense mechanisms to avoid or hold up various oxidative stresses (Roesijadi 1996). This observation was also confirmed by Johari et al. (2016).

Comparatively, with other animal taxa, Mansour et al. (2012) observed that animals such as mice living in contaminated environments exhibited distinct isozymes and/or protein subunit pattern separations. These observations could be utilized for the bio-exploring of various environmental stresses. As known, the enzymes reflect the differential expression of genes. Also, it is responsible for the differential expression of genes through their participation in the control of transcriptional and posttranscriptional actions (Paigen, 1979; Scandalios, 1979). The same conclusion was revealed by Pedrajas et al. (1993) in the Mullet and Abd EL- Reheem et al., (2007) in Tilapia fishes.

The amount of some enzymes such as Sod (protects cells against oxidative stress) and their corresponding gene expression (Choi et al., 2010; Johari et al., 2016) is vital as a biomarker of environmental stresses in various aquatic ecology. The numbers and intensity levels of these biomarker isoforms and/or expressions had differed from tissue to tissue under the same experiment condition. So, in the current investigation, an increase in Sod isoforms (through time) were detected in the fish gill tissue extracts following exposure to AgNPs. Compared with the control, the numbers of Sod bands were decreased following exposure to AgNPs in the eye tissue extract separation. Comparatively, with other fish tissues, Choi et al., (2010) observed that the gene expression levels of superoxide dismutase did not alter in the zebrafish liver tissues following exposure to AgNPs. Esterase isozyme activities and separations were intensively evaluated in many animal taxa (Saad et al., 2009; Mansour et al., 2012) including fishes. The Esterase isozymes are identified by their common activity with many naphthylester substrates. These isozymes are frequently monomeric (Cruz et al., 1982). So, each identified esterase band represents the end product of one locus (allele). In the present study, the $\alpha$ - naphthylacetate as substrates were used to identify Esterase bands revealed under experimental conditions. The wide tissues-distribution of esterase suggests that this enzyme may be a housekeeping protein that serves a general metabolic function characteristic of all cell types (Holmis and Whitt, 1970).

\section{CONCLUSION}


Comprehension of the probable effects of silver Nanoparticles on fish is chiefly significant. We evaluated the effects of silver nanoparticles (synthesized using the green method) on the P.scalare biological responses. The homogeneity among the fish samples was evaluated via the analysis of Inter simple sequence repeat (ISSR) variations. Fishes were reared for certain times under silver nanoparticle stresses. Protein electrophoresis and four isozyme systems (Est., Mdh, Adh and Sod) and (polyacrylamide gel electrophoresis) were assayed to identify genetic markers (as bioindicators) in the three different fish tissues (eye, gill and muscle) for all evaluated fish groups. We found that exposure to AgNPs can change the number and intensity of Esterase, Malate dehydrogenase and Superoxide dismutase in certain fish body organs. Isozyme separations have proven to be actual probes of differential gene expression in various fish samples. More biochemical markers could be developed to monitor aquatic environmental health especially in the term of water pollution ranks in the future Eco-toxicological investigations.

\section{ACKNOWLEDGMENT}

We thank Dr. Heba E.A. Elsebaie, Researcher at the National Institute of Oceanography and fisheries, Egypt, for her expert advice on fish rearing and computer analysis. Also, we thank the conservation of Biological aquatic resources research group, Department of Biological Sciences, Faculty of Sciences, King Abdulaziz University, Kingdom of Saudi Arabia, for provision the bark extracts and fish samples.

\section{REFERENCES}

Abd EL-Reheem, M. A.; Saad, Y. M.; Sallam; M. A. and Tantawy, T. M. A. (2007). Responses of some Tilapia genomes to oleic acid. Journal of biological chemistry and environmental sciences, 2 (4): 407 - 430.

Choi, J.E.; Kim,S.; Ahn, J.H.; Youn, P.; Kang, J.S.; Park, K.; Yi, J., Ryu, D.Y. (2010). Induction of oxidative stress and apoptosis by silver nanoparticles in the liver of adult zebrafish. Aquat Toxicol, 100 (2):151-159.

Chae, Y.J.; Pham, C.H.; Lee, J.; Bae, E.; Yi, J. and Gu, M.B. (2009). Evaluation of the toxic impact of silver nanoparticles on Japanese medaka (Oryzias latipes). Aquat Toxicol, 94:320-327.

Cruz,T.; Thorpc, J. and Pullin, R. (1982). Enzyme clectrophoresis in Tilapia :illii: a pattern 1'or determining biochemical genetic markers for use in tilapia stock identification. Aquaculliire, 29: 311-329.

Fianko, J. R.; Donkor, A.; Lowor, S. T.; Yeboah, P. O.; Glover, E. T.; Adom, T. and Faanu, A. (2011). Health risk associated with pesticide contamination of fish from the Densu river basin in Ghana. Journal of Environmental Protection, 2:115-123. 
EL-Sebaie, H.E.A., Mahmoud, N. H.; Mahmoud, H. I. and Saad, Y. M. (2014). Biological Performance of Pterophyllum scalare larvae Fed on Artemia and Artificial Diet. World Journal of Fish and Marine Sciences, 6 (3): 289-294.

Farkas, J.; Iurgi, S.; Bjarne, S.; Radka, S.; Tomasz, M.; Anders, J.; Wilfried, P.; Trond, P.; Krokje, A.; Salvenmoser, W. and Jenssen, B. M. (2017). Exposure of juvenile turbot (Scophthalmus maximus) to silver nanoparticles and $17 \alpha-$ ethinylestradiol mixtures: Implications for contaminant uptake and plasma steroid hormone levels. Environmental Pollution, 220: 328-336.

Fore, S. A.; Guttman, S. I.; Bailer, A. J.; Altfater, D. J.; and Counts, B.V. (1995). Exploratory analysis of population genetic assessment as a water quality indicator. Ecotoxicology and Environmental Safety, 30: 24-35.

Gulec, K. A.; Altinterim, B. and Aksu, O. (2013). Determination of lethal concentration (LC50) values of Cinnamomum zeylanicum hydrosol on carp fish. Iranian Journal of Fisheries Sciences, 12:34-44.

Hogstrand, C.; Wood, C. M.; Bury, N. R.; Wilson, R. W.; Rankin, J. C. and Grosell, M. (2002). Binding and 532 movement of silver in the intestinal epithelium of a marine teleost fish, the European flounder (Platichthys flesus). Comp. Biochem. Phys. C, (133): 125-135.

Holmes, R.S. and. Whitte, G.S .(1970). Developmental genetics of the esterase isozymes of funduls heteroclitus. Biochem. Genet.,4:471-480.

Ibrahim, A.T.; Banaee, M. and Sureda, A. (2021). Genotoxicity, oxidative stress, and biochemical biomarkers of exposure to green synthesized cadmium nanoparticles in Oreochromis niloticus (L.). Comparative Biochemistry and Physiology Part C: Toxicology and Pharmacology, 242: 108942.

Johari, S.A.; Kalbassi, M. R.; Lee, S. B.; Dong, M. S. and Yu, I. J. (2016). Silver nanoparticles affects the expression of biomarker genes mRNA in rainbow trout (Oncorhynchus mykiss). Comp Clin Pathol, 25:85-90.

Johari, S.A.; Kalbassi; M.R.; Yu, I. and Lee, J. (2015). Chronic effect of waterborne silver nanoparticles on rainbow trout (Oncorhynchus mykiss): histopathology and bioaccumulation. Comp Clin Pathol, 24, 995-1007.

Laura, C.; Ana; R. Alvarez and Claudio H. M. (2020). Silver nanoparticles (AgNPs) as antimicrobials in marine shrimp farming: A review. Aquaculture Reports, 18:100512.

Mansour, A.A.; Salam, M.A. and Saad, Y. M. (2012). Mice (Mus musculus) genome responses to methotrexate (MTX) and some plant extracts. Life Sci J, 9(4):48814886.

Omar, A.; Saad, Y. M. and Hasawi, Z. M. (2020). Evaluation of DNA polymorphism in the Red Sea Epinephelus species using 12s rRNA and Inter simple sequence repeat. Indian Journal of Geo-Marine Sciences,49(7):1197-1205.

Ozgur, F. and Rifat, C. (2018). Assessment of biochemical and toxic responses induced by titanium dioxide nanoparticles in Nile tilapia Oreochromis niloticus, Human and Ecological Risk Assessment: An International Journal, DOI: 10.1080/10807039.2018.1465338 
Paigen, K. (1979). Genetic factors in developmental regulation. In J. G. Scandalios (ed.), Physiological genetics, pp. 1-61. Academic Press, New York

Pasteur, N.; Pasteur, G.; Bonhomme, F.; Catalan, J. and Britton-Davidian, J. (1988). Practical Isozyme Genetics. Ellis Horwood Limited, Chichester, 215.

Pedrajas, R.; Peinado, J. and López-Barea, J. (1993). Purification of Cu, ZnSuperoxide Dismutase Isoenzymes from Fish Liver: Appearance of New Isoforms as a Consequence of Pollution. Free Radical Research Communications, 19:1, 29-41.

Pham, C.; Yi, J. and Gu, M.B. (2012). Biomarker gene response inmale Medaka (Oryzias latipes) chronically exposed to silver nanoparticle. Ecotoxicol Environ Saf, 78:239-245.

Rao, P. S.; Babu, N. B. and Raju, R. R. (2010). Study the effect of chlorpyrifos on proteins in freshwater fish Labeo rohita by using HPLC Method. International Journal of Research in Pharmaceutical and Biomedical Sciences 1: 1-5.

Rashed, M.A.; Badawy, E. A.; Saad Y. M. and Abd EL-Rasek A. B. (2007). Genetic signature of some Egyptian Hemichromis bimaculatus fish Populations based on muscle protein polymorphism. Egypt. J. Aquat. Biol. And Fish,11 (1): 83- 100.

Rahman, A.; Kumar, S.; Bafana, A.; Dahoumane, S. A., and Jeffryes, C. (2018). Biosynthetic Conversion of $\mathrm{Ag}^{+}$to highly Stable $\mathrm{Ag}^{0}$ Nanoparticles by Wild Type and Cell Wall Deficient Strains of Chlamydomonas reinhardtii. Molecules (Basel, Switzerland), 24(1): 98.

Roesijadi, G. (1996). Metallothionein and its role in toxic metal regulation. Comp Biochem Physiol, Part C, 113(2):117-123.

Robert, W.M.; Jack W. S.; Donald G.B.; and Christopher, H. H. (1996). Isozyme electrophoresis. In: Molecular Systematics. 2nd edition. David, M.H., et al. eds.,Sinauer Associates, Inc., underland, U.S.A., 51-120.

Saad, Y. M. and Heba, E. A. EL-Sebaie (2020). Evaluation of morphometric and molecular variations among some Egyptian brine shrimps comparatively with other Artemia species. Egyptian Journal of Aquatic Biology \& Fisheries. 24(1): $337-347$.

Saad, Y. M.; A. A. Mansour, and EL-Nagar, A. M. (2009). Monitoring of genetic polymorphism in some tilapia species based on fin tissues isozyme distributions. World Journal of Zoology, 4(1):24 - 28.

Saad, Y. M.; Abu Zinadah, O. A. H. and El-Domyati, F. M. (2013).Monitoring of genetic diversity in some parrotfish species based on inter simple sequence repeat polymorphism. Life Sci J.,10(4):1841-1846.

Sabullah, M. K.; Ahmad, S. A.; Shukor, M. Y.; Gansau; A. J., Syed, M. A.; Sulaiman, M. R. and Shamaan, N. A (2015).Heavy metal biomarker: Fish behavior, cellular alteration, enzymatic reaction and proteomics approaches. International Food Research Journal, 22(2): 435-454.

Scandalios, J. G. (1979). Control of gene expression and enzyme differentiation. In J. G. Scandalios (ed.), Physiological genetics, pp. 63-107 Academic Press, New York. 
Sharma, V.K.; Yngard, R.A. and Lin, Y., (2009). Silver nanoparticles: green synthesis and their antimicrobial activities. Adv. Colloid Interface Sci, 145: 8396.

Skuratovskaya, E.; Kovyrshina, T. B. and Rudneva, I. (2017).A Comparative Study of Long-Term Pollution Effects of Marine Waters on the Blood Biomarkers of Two Benthic Fish Species: the Scorpion Fish Scorpaena porcus (Linnaeus, 1758) and the Round Goby Neogobius melanostomus (Pallas, 1814) from the Black Sea. Russian Journal of Marine Biology, 43 (3): 232-238.

Xia, T.; Li, N. and Nel, A. E. (2009). Potential health impact of nanoparticles. Annu Rev Public Health., 30:137-150.

Baun, A.; Hartmann, N. B.; Grieger, K. and Kusk, K.O. (2008). Ecotoxicity of Engineered Nanoparticles to Aquatic Inverte brates: A Brief Review and Recommendations for Future Toxicity Testing. Ecotoxicology, 17: 387-395.

Warheit, D.B.; Hoke, R.A.; Finlay, C.; Donner, E.M.; Reed K. L. and Sayes, C.M. (2007). Development of a Base Set of Toxicity Tests using Ultrafine TiO2 Particles as a Component of Nanoparticle Risk Management. Toxi col. Lett, 171: 99-110.

Klaine, S.J.; Alvarez, P.J.; Batley, G.E.; Fernandes, T. F ; Handy, R. D.; Lyon, D. Y; Mahendra, S.; McLaughlin, M. J; Lead, J.R. (2008). Nanomaterials in the Environment: Behavior, Fate, Bioavailability, and Effects. Env. Toxicol. Chem., 27:1825-1851.

Murphy, C. J.; Sau, T. K.; Gole, A. M.; Orendorff, C. J.; Gao, J.; Gou, L.; Orendorff, C. J., Gao, J.; Gou, L.; Hunyadi, S.E. and Li, T. (2005). Anisotropic metal nanoparticles: synthesis, assembly, and optical applications. J. Phys. Chem. B.,109:13857-70.

Griffitt, R. J.; Luo, J.; Gao, J.; Bonzongo, J. and Barber, D. S. (2008). Effects of Particle Composition and Species on Toxicity of Metallic Nanoma terials in Aquatic Organisms. Env. Toxicol. Chem., 27:1972-1978.

Griffitt, R. J.; Weil, R.; Hyndman, K.A.; Denslow, N. D.; Powers, K.; Taylor, D. and Barber, D. S. (2007). Exposure to Copper Nanoparticles Causes Gill Injury and Acute Lethality in Zebrafish (Danio rerio). Env. Sci. Techn., 41:8178-8186.

Lee, K. J.; Nallathamby, P.D.; Browning, L.M.; Osgood, C. J. and Xu, X. N. (2007). In Vivo Imaging of Transport and Biocompatibility of Single Silver Nanoparticles in Early Development of Zebrafish Embryos. ACS Nano, 1:133143. 